Why should archaeology matter to the History of Science? Historians of science have long considered the histories of archaeology and antiquarianism beyond their purview, even as archaeologists have consistently claimed their work to be part of the natural sciences. ${ }^{1}$ As Margarita Díaz-Andreu wrote, "historians of science (whether philosophers, epistemologists, historians of science, or sociologists of science) have been stubbornly reluctant to deal with archaeology in favour of other disciplines such as geology and medicine". ${ }^{2}$ The history of archaeology has been — and often continues to be — a strictly disciplinary endeavour. ${ }^{3}$

Yet what is striking is the instability and diversity of archaeology, in addition to its global success as a phenomenon well beyond what is usually called a discipline. Doubtless thanks to Foucault, the category "archaeology" now appears everywhere: history and literature, philosophy and law. ${ }^{4}$ And the word's resonance in terms of the history of science is clear. For instance, beyond archaeology's long connection to the natural sciences, in the nineteenth century the promoters of the nascent social sciences saw the practice as constituting a method that mirrored the role of statistics. ${ }^{5}$ That this claim was made might seem remarkable, but only goes to demonstrate that the archaeological phenomenon deserves more scholarly attention than it has so far received.

As the articles in this special issue demonstrate, disassembling archaeology and examining its practices and procedures, appropriations and circulations, we find a complex domain of intellectual and practical knowledge that helps us to reassemble the ways in which we think about science, modernity and the world. ${ }^{6}$ In order to aid this reassembly, this essay discusses issues in the history of archaeology in order to help historians of science reprioritize their understandings of the discipline, its past and the pasts that it helps to create. The history of archaeology matters. Yet in order to clarify the ways in which it matters, this essay reframes the manner in which we think about the history of the discipline, emphasising the resonances between the history of archaeology and the history of science and questioning the boundaries that currently exist between the two fields.

\title{
Archaeology, Antiquarianism and Science
}

Addressing the interpretation of mounds in France in the 1810 Mémoires de l'Académie celtique, Jacques-Antoine Dulaure alerted his colleagues against viewing such entities as selfevidently cultural, emphasising instead a methodology of cautious empirical observation: 
stones. Let us not assign to art productions of Nature; let us distrust what we want to believe; let's enthusiastically observe, describe and then gradually come to conclusions. When our findings suggest some uncertainty, let us express our doubts and give those findings time before they become reality. These ideas are suggested by the stone that I have just described. I dare not say that it is a monument of the ancient religion of the Celts, nor that its position is only the effect of the revolutions suffered by our globe. ${ }^{7}$

In The Discovery of the Past, Alain Schnapp demonstrated that the specification of archaeological practices relied not only on making use of the philological disciplines, but also on making use of the methodologies of the natural sciences. At its heart, the specification of the archaeological approach involved deciding whether to differentiate the archaeology of natural history in its material dimensions. ${ }^{8}$ Claiming to be a natural science, archaeology-as Dulaure's intervention emphasizes_-was instrumental in securing new regimes of proof, evidence and certainty, and re-scaling the past through the use of instruments and measures. Antiquarianism therefore became a science of objects and monuments: archaeology. As Schnapp wrote, "the [eighteenth-century antiquarian] Comte de Caylus proposed to replace the philological model with an experimental one, in contrast to the classical description and interpretation, and to turn the antiquity into a kind of physicist of the past". 9

Yet this process was not without contention, and tension between disciplines and regimes of scientificity remains important in archaeology. Perhaps more than any other issue, then, this tension emphasizes the interest that the history of archaeology should hold for historians of science. Most notoriously, in the last fifty years, theoretical issues raised by the so-called New Archaeology and post-modernist, 'post-processual' approaches to archaeological work have had this tension at their heart. ${ }^{10}$ But such tension was also present within archaeological work before the discipline's explicit and rather self-conscious relationship with theorising began. In 1954, for example, the British archaeologist Mortimer Wheeler pronounced that "there is to-day a genuine risk of a new severance between humanism and science in [understanding the past] ... just at the time when a closer integration of the two is feasible and necessary". ${ }^{11}$ How has such tension manifested itself, and why?

In order to answer these questions, we must reflect further on the historical specificity of the relationship between archaeological and antiquarian knowledge, bearing in mind archaeologists' tendency to use antiquarianism as a straw man with which to compare their 
own claims to rational, scientific status. ${ }^{12}$ How did scientific/scientistic archaeological knowledge start to form, why, and what was the connection of this process to the forms of antiquarian scholarship from which archaeology developed? Before the involvement of the natural sciences, practices connected to the investigation of the past had long constituted a regime of knowledge based upon philology and commentary; a regime that considered the past primarily as a text referring to ancient sources. From the Renaissance onwards, medieval charters became the main basis of a dramatic revision of the narrative of the past as antiquarians entered into a long process of negotiating and validating historical statements. ${ }^{13}$ In recent years, the discovery that documents constituted a site of knowledge has both energized cultural history and history of science, whose practitioners have considered the importance of 'inscriptions' as crucial steps in the production of epistemological truths. ${ }^{14}$ Clarifying the negotiated process through which this epistemological production took place can help us to understand the scientific tensions present within the history of the archaeological discipline.

Unfortunately, the history of antiquarianism remains an overwhelmingly European narrative, despite recent moves to make it less so. ${ }^{15}$ Yet even within these limited (if expanding) boundaries, antiquarian discoveries were only accepted after several acts had taken place whose parameters offer strong potential for the use of modes of analysis from the history of science. The first act involved submitting those discoveries to the criticism of the scholarly community. The second involved the settlement of controversies related to history, especially concerning the use of oral accounts and the validity of ancient traditions. To resolve these controversies and persuade their scholarly peers, early modern antiquarians first relied on comparative philology and then drew on non-textual traces in the form of numismatic and artefactual evidence. Such scholars then started to prefer physical traces to translations of ancient texts and began re-examining ancient ruins. For example, the French lawyer Henri Sauval's major innovation lay in his discussion of "archaeological discoveries". ${ }^{16}$ Digging became a new learned practice, and the ways in which it did so are amenable to the history of science's analytical tools. Meanwhile, another potential area of research is the 'visual turn' which emerged at the beginning of the eighteenth century and which made drawing a tool used to record and compare monuments and objects. The foundation was laid for graphic representations to become the basis of archaeological practices; significant amounts of material exist for investigation as part of the history of scientific representation. ${ }^{17}$ 
The accumulation of field data, cartography and archives constituted archaeology as a new intellectual and analytical domain, and the resonances of this development with issues in the history of science are clear. Whilst not all dealing with the relationship between archaeology and antiquarianism, the essays in this special issue reflect on historical moments when the archaeological domain has come into being or been re-constituted in order to demonstrate the ways in which this process can resonate with this wider analytical frame. For instance, Stéphane Van Damme's article addresses an episode in which the development of the category of the archaeological object was involved in the (re-) ordering of the Parisian past at multiple scales, and William Carruthers discusses a moment in the mid-twentieth century when the traditional tenets of archaeological practice in Egypt suddenly had to be rearranged. Additionally, Melania Savino focuses on visual media in order to illustrate the historical contingency of archaeological objects in Turkey. Christina Riggs, meanwhile, discusses how one of the modes through which archaeologists came to register the past is telling of the historical contingency of archaeological field labour. Riggs uses one particular form of scientific representation located within the archaeological archive (the photograph) to illustrate how a facet of the history of archaeological field work might be discovered and reassembled. Yet there are other facets of the field that might be reassembled, too.

\section{Archaeological Field Notes: (Dis)order and Scale, People and Place}

Recapping the (pre-)history of archaeology, it has been difficult not to paint a picture of order: of an intellectual and practical domain ultimately becoming secure within its boundaries. Yet, following Philippe Boissinot, this special issue discusses archaeology as a phenomenon that, across the various scales with which it is associated, does not always operate with the solidity and order that its connection to the terms 'domain' or 'regime' might suggest. Boissinot considers that archaeologists are always in search of past intention and rationality. They are consequently threatened by the problem of 'archaeological emptiness' (vide archéologique) that occurs when intention and rationality cannot be located or constituted by their work. ${ }^{18}$ Boissinot's supposition provides an extremely valuable analytical tool regarding the history of archaeology, especially when considering certain literature in the history of science.

Placing the history of archaeology within the framework of this literature illustrates how the history of fieldwork in the archaeological 'domain' in fact contributes to larger discussions about place and scale. Questions relating to the field have taken on a certain- 
although not expansive-importance within the history of science. What, if anything, makes scientific fieldwork different from scientific work elsewhere, and what place-making practices does fieldwork generate? How, too, can work undertaken in the field be mobilized to work in other places and at other scales? ${ }^{19}$ Responding to such questions by using the example of field biology, Robert Kohler discussed the notion of hybrid 'border practices' designed to make field scientific work compelling to laboratory practitioners. Yet Kohler also made clear the frustrating field experiences that led to this hybridity coming into being. ${ }^{20}$ The notion of 'archaeological emptiness' suggests that not only field biologists have experienced such frustration.

From the moment of commencing excavation (if not before), archaeologists are concerned with formulating proof and evidence and managing its movement across scales: not only from site to institution (government antiquities department, university or museum), but also to published literature and in terms of that evidence's applicability to various (local, national, international) scales of explanation. In the history of archaeology, though, it is clear that during the act of excavation much frustration has also occurred. During excavation, a constant, low-level state of archaeological emptiness is generated that points to a way in which the field experience in archaeology can add depth and nuance to other understandings of scientific fieldwork.

For example - anticipating the discussion of archaeology, empire and circulation below-thinking about tensions related to labour and archaeological excavation provides one way of making such archaeological emptiness productive to wider discussions about the field. Excavations in countries, like Egypt, at the heart of imperial and colonial history have often (although not always) been dependent on hiring local workers to carry out the actual work of digging: men, women and children whose livelihoods are supplemented by the wages that foreign archaeological missions in particular provide. Historical research has started to demonstrate that these hired labourers not only possessed significant archaeological skill (perhaps more so than the foreigners who took charge of them), but also that they could easily disrupt the excavation work being carried out. ${ }^{21}$ How has reliance on field labourers constituted archaeological evidence and the ways it can move across various scales? And how does this history differ from, say, the use of field assistants and informants in the history of anthropology or the use of technicians in laboratory science?

Accessing material related to archaeological field labour can provide answers to such questions, indicating the potential of the history of archaeology to inform wider discussions about the role of collective labour in the history of science. In this special issue, for instance, 
Christina Riggs addresses the labourers captured in photographs of the excavation of the tomb of Tutankhamun during the 1920s. Riggs uses these photographs and their story to think about the discursive act of representing these labourers at work in the field: an act that contributed to archaeology's self-representation as a scientific practice, but also an operation that reveals in stark outline the collective, asymmetrical nature of colonial archaeological field practice. By demonstrating this link, Riggs adds to our understanding of the ways in which the ability to assert archaeology's (often heroic, and often male) scientific authority beyond the field site has rested upon the authority to control the place and identity of the workers and assistants within it. Steven Shapin's “The Invisible Technician" made clear that scientific work involved more than lone practitioners, and in fact was dependent upon an entire cast of characters whose work was relegated to the background. ${ }^{22}$ But as Riggs' article makes clear, representational practices in colonial archaeology constituted an act with the same intention to relegate, yet also an act which ironically resulted in making relegated workers visible.

The history of archaeological fieldwork, meanwhile, also throws up issues relating to the intersection between materiality and the movement of proof across scales. How have archaeologists depicted material evidence in order that it might transcend the scale of the field and how, if at all, do issues related to the materiality of archaeological work make these efforts differ from the act of representing laboratory practice? Archaeological emptiness might well be considered a side-effect of the problems of dealing with such materiality. Few detailed discussions of archaeological field practice exist, but those accounts that do exist highlight the field's contingency, complexity and anxiety. Work at the site of Çatalhöyük in Turkey, for instance, has explicitly addressed such issues from the moment that it restarted in the early 1990s. ${ }^{23}$ Returning to Tutankhamun, meanwhile, Elliott Colla's discussion of the excavation of the pharaoh's tomb makes clear the care taken to overcome the material contingency of the artefacts found there through their registration as property of the (nominally) independent Egyptian state and not their British excavator and his sponsor.

Scaled up to the level of Egypt's borders, the tomb's artefacts could not be removed from the country, erasing the otherwise troublesome identity of the recovered objects. ${ }^{24}$

In this special issue, William Carruthers expands on such research through a detailed account of work at an archaeological site whose material contingencies placed issues of scale and authority centre stage; an account which dovetails with the issues of field labour discussed by Riggs. At the site of Mit Rahina, an Egyptian-American team led by the University Museum of the University of Pennsylvania struggled to excavate an ancient city. 
Quite literally bogged down in excavation trenches, the team's leadership began to lose control of their workforce, calling into question the self-appointed, Cold Warrior-style expertise supposedly provided by the University Museum participants. A representation of an archaeological section at the site constituted an attempt to overcome this issue: the method used to make the representation apparently placed the site on a global, comparative scale in order to nullify local problems. Yet these problems could not be overcome and the representation failed in its purpose. In the archaeological field, issues of material and proof, authority and scale constituted significant concern. This special issue suggests the need for further investigation of these intersections and the issues of power and epistemology that they raise.

\section{Publicizing Archaeology: From Professionalization to Public Concerns}

As this essay's discussion of life in the field makes clear, the renewal of epistemological questions relating to the making of archaeological knowledge must also intersect with a renewal of the social history of archaeology, not least in an examination of questions relating to the tension between professionalization of the discipline and the constitution of public concern relating to it. Despite much received opinion, neither archaeological professionalization nor the emergence of the archaeological past and/or heritage as a public concern were spontaneous events. Instead, as recent literature has started to demonstrate, these undertakings involved a slow, tense and ongoing process of social negotiation ripe for further investigation. ${ }^{25}$ Even as a culture of amateur practice remained strong within archaeology, this process related to the creation of administrative apparatuses that constituted not only the national past, but also the professionals who could speak for and carry out work related to it. ${ }^{26}$ Complicating our understanding of the place and social characteristics of the archaeological field, this process was also tied to various other issues: urbanism, transnationalism, class and gender all feature, highlighting the place of the history of archaeology at the centre of issues of interest to the history of science.

For example, in Britain, twentieth-century figures like Mortimer Wheeler, O.G.S. Crawford and Kathleen Kenyon are often credited with furthering the professionalization of archaeological work. ${ }^{27}$ Yet this process — and others like it — had been occurring for a significantly longer period. For example, the foundation of the journal Archaeologia (1770), published bi-annually by the Society of Antiquaries of London, or the regular presence of articles in publications like the Gentleman's Magazine stimulated the emergence of a 
(gentlemanly) archaeological journalism and provided a forum to alert the educated public about it. ${ }^{28}$ Moreover, Archaeologia enabled the Society of Antiquaries to develop its links with foreign learned societies through the exchange of volumes. And the production of the journal also contributed to the recognition of London society as a metropolitan centre of antique knowledge in the eyes of provincial scholars such as John Whitaker of Manchester or historian John Watson of Halifax. ${ }^{29}$ Between 1770 and 1820, the eighteen volumes of Archaeologia demonstrate a complete reversal in terms of what constituted acceptable evidence about the past: a move away from the Roman period to the English medieval era, and an interest in archaeological artefacts rather than manuscripts. ${ }^{30}$ Yet the number of people involved in this change illustrates just how permeable disciplinary boundaries were: scholars, engineers working on municipal projects, architects and a wide range of amateurs and collectors all contributed to Archaeologia's reorientation of what the past constituted. The parameters of this permeability call out for investigation.

Meanwhile, such processes started to take on a distinctly national character, and the issues of authority which they generated themselves hint at the need for further research into the histories surrounding them. Again taking the British example, the first congress of the British Archaeological Society was held in Canterbury in 1844, accompanying the rise of historical scientific societies at national level including the Numismatic Society (1836), the Historical Society of Science (1840), the Royal Historical Society (1868), the Society for Biblical Archaeology (1870), the Society for the Protection of Ancient Buildings (1877), the Folklore Society (1878) and the Egypt Exploration Fund (1882). Londoners constituted a large proportion of the memberships of these societies: in 1845 at the Archaeological Institute, they represented $26 \%$ of members, and at the British Archaeological Society they constituted $25 \% .{ }^{31}$ Ultimately, this rise in national professional societies led to universitybased historians supplanting gentlemanly antiquarians. Simultaneously, archaeological museums were opened and the press mobilized urban public space through issues related to preserving ancient remains recovered within it. ${ }^{32}$ Yet even then this process was gradual: despite the accession of W.M.F. Petrie to the new Edwards Professorship of Egyptology at University College of the University of London in 1892, the knowingly professional Journal of Egyptian Archaeology only began publication in $1914 .{ }^{33}$ How and why did such processes of national, urban professionalization solidify, and what types of authority did they generate by doing so?

This question also relates to the circulation of knowledge. For example, in 1898, the new Commission of Old Paris sent major western cities an extensive questionnaire in order to 
understand their public policy relating to the past. Aachen, Amsterdam, Athens, Berlin, Brussels, Cologne, Dresden, Florence, Frankfurt am Main, Genoa, Glasgow, Liverpool, Milan, Moscow, Munich, Odessa, Palermo, Valencia and Warsaw all sent replies, and such enquiries about the management of the urban past helped to establish new, urban institutions of modernity like the town-as-museum on a national and transnational basis. ${ }^{34}$ Yet this process was not without its struggles. Tension grew as individuals who saw themselves as having a stake in the past found themselves excluded from the new professional cadres. Indeed, the tension between modernity and antiquity, professionalization and amateurism became particularly acute as authoritarian regimes developed in Europe during the first half of the twentieth century. In Italy, for instance, a vision of fascist modernity was generated from the ideals of discipline, virtue and order that Italian archaeologists projected onto the ancient Roman past: the concept of romanità was manipulated to reinforce the fear of modernity as a blind force of change. ${ }^{35}$ Yet Italian national culture relating to the past has always been shaped at the margins of society, too: tombaroli (illicit diggers; sing. tombarolo) have been consistently condemned for conducting clandestine excavations, but have also always expressed their own ideas about the meaning and value of the objects that they excavate. ${ }^{36}$ How do we understand the relationship between transnational circulation, national pasts and dispossessed local populations?

This question has ramifications beyond Europe. In the well-known case of Egypt, imperial competition between Britain and France resulted in an Egyptian Antiquities Service whose tenets possessed legislative presence in the Entente Cordiale: run by a French director, the institution's upper-level staff was comprised of French and British men, whilst Egyptians were confined to lower ranks. Despite growing Egyptian attempts to gain a larger role in managing and teaching the national past, it was only after the overthrow of King Faruq during the Free Officers' coup of 1952 that an Egyptian, Mustafa Amer, would take charge of antiquities administration in the country. ${ }^{37}$ In his paper in this special issue, William Carruthers discusses the aftermath of these events in terms of the new practices that they engendered. In her paper, meanwhile, Melania Savino discusses a comparative case: the changing use of photography at archaeological sites in Kemalist Turkey. Generating positive depictions of the relationship between archaeologists and their public, photography here constituted a scientific tool imbued with social intention. What engendered this situation, and why? Savino's article provides original answers. Yet Savino's work also hints at the need to provide such answers whilst taking into account a global historical perspective. 


\section{Archaeology's Empires: Transnational Circulation, Knowledge and the Continued Relevance of Scale}

Much as in the history of anthropology, the sort of Colonial (and other) Situations discussed above often embodied attempts to overcome tensions between archaeological professionals and their local publics. ${ }^{38}$ For instance, Indra Sengupta has discussed the difficulties that colonial officials in India experienced when trying to implement practices related to the country's 1904 Ancient Monument Preservation Act. Using a handbook developed to allow the implementation of the Act's guidelines (itself not dissimilar to a number of other handbooks circulating in Britain and Europe), officials of India's Department of Archaeology struggled when dealing with religious monuments: Sengupta gives the example of the Jagannath temple at Puri, whose boundaries were indivisible from the space and communities surrounding it. Ultimately, officials were unable to fence off a pillar located within the temple due to the combined force of the institution's management and the wider sentiment of the local community. ${ }^{39}$ The (imperial, transnational) bounding of the past intersected with local realities.

Yet understanding such interactions further will involve overcoming a deep-set narrative connected to the history of archaeology. Despite the clear and complex transnational characteristics of archaeological events such as that occurring at Puri, since Bruce Trigger published his well-known article "Alternative Archaeologies: Nationalist, Colonialist, Imperialist", we have habitually associated a 'global' or 'world' history of archaeology with reflection on the relationship between bounded categories of nationalism, colonialism and imperialism. By constituting a historical typology of archaeology, Trigger inadvertently constituted a structure that (still) defines the way we think about archaeology's presence around the world. ${ }^{40}$ In many instances, though, the categories connected to this structure are too broad and too blunt to be of significant analytical use beyond the jolt provided by their initial application. For instance, in her compendious World History of Nineteenth-Century Archaeology, Margarita Díaz-Andreu uses "informal imperialism” as a category with which to think through the intersection between archaeology and imperial and colonial expansion across the globe. ${ }^{41}$ Yet it is clear that this relationship functioned differently in each of the places she discusses: the nineteenth-century Ottoman Empire, for instance, was neither nineteenth-century Japan nor nineteenth-century China, and we cannot therefore explain this intersection using one, overly broad category. Much as discussions of orientalism have moved beyond Edward Said's initial broad polemic to a more nuanced 
understanding of the history of orientalist practices, so discussions of the history of archaeology (themselves overlapping with the history of orientalism) need to move beyond overly broad understanding too. ${ }^{42}$

This call for nuance is, then, a call to follow wider work in the history of science in order not only to understand better the various scales and categories of analysis that resonate with the history of (imperial and other sorts of) archaeology, but also to understand the way that knowledge about the past circulated between them. As Secord noted, knowledge operates "in transit". ${ }^{43}$ We need to investigate the processes and procedures of this transit in order to understand how the different scales of archaeology have worked and come together. What and who allows knowledge to move between such scales, and why? How, as Sivasundaram has discussed in a different context, can we think about such questions of scale in order to decentre narratives of 'imperial' archaeology that in fact reify bounded notions of western and national(ist) science? ? $^{44}$

Answering this last question is particularly vital, since so many of the accounts of archaeology in the ages of imperialism, colonialism and beyond focus on and help to reproduce a narrative in which western excavating missions 'encounter' nationalist contention, and never the twain shall meet. ${ }^{45}$ To some extent, these accounts result from a particular, somewhat positivist reading of the most readily accessible archival material; a reading also conditioned by its production in the Euro-American academy. Scholars, limited by issues of language, have written histories focusing on western archaeological archives, the inevitably bounded accounts of imperial and colonial encounter found within them and, also, the gendered male narratives that the names attached to archaeological publications from the era seem to present (despite the consistent presence of, and work in, the colonial field of wives and women 'assistants' like Hilda Petrie). ${ }^{46}$ Yet even this archival material should allow historians to produce more complex accounts of the circulation of knowledge if it is used creatively and with a critical focus on the production of the archive itself. Moreover, it is becoming abundantly clear that material - 'archival' or otherwise - held outside of the western sphere can be used to create new, complex and multi-scalar historical narratives. Thinking about the postcolonial, multilateral age, when organisations like UNESCO not only constitute 'world' heritage through operation at a variety of scales, but have also enjoyed a significant amount of relevance in decolonising countries, interest in creating such narratives should be high. ${ }^{47}$

Indra Sengupta's account of the multiple scales in operation at the Puri Jagannath temple provides one example of the sort of work that we argue histories of archaeology 
should now focus on. But all the articles in this special issue also rethink matters of scale and the circulation of knowledge in some way. By concentrating on the field, both Christina Riggs and William Carruthers illustrate that the creation of colonial and post-colonial knowledge at scales beyond the local was dependent on both the control of labour and also the control of the materiality of excavation itself. Meanwhile, as discussed in more detail below, Melania Savino shows how the arrangement of archaeological objects at the scale of the museum display case served to build identity at the level of the early, post-Ottoman Turkish republic. Finally, Stéphane Van Damme shows how even the changing ways of studying one ancient object in particular enabled archaeology to become a discipline relevant to, and circulating between, several different scales at once. No longer does the history of archaeology need to be either "Nationalist, Colonialist, [or] Imperialist", and nor should it be.

\section{Visualizing or Materializing the Past? Museums, Collections and Archaeological Objects}

How have the histories of museums and collections aligned with the history of archaeology? How have collectors and curators used the visual and material technologies available to them to construct understandings of what the past is? Addressing these questions will not only allow us to complicate the institutional history of the museum in general, but will also help us to align the history of archaeology with the history of scientific visualisation. ${ }^{48}$ Moreover, the study of the lives and careers of archaeological objects that addressing such questions allows connects productively to recent reflections on materiality in the history of science and knowledge production more generally. ${ }^{49}$ There is, of course, nothing original about aligning the history of archaeology with discussions of museums and their place in the history of science. Yet archaeology has sometimes seemed to take second place to discussions of natural history and anthropology as scholars have sought to understand the role of the museum as a 'total', knowledge-producing institution. Simultaneously, work in museum studies has drawn attention to just how complex the development of these institutions has been. This work has also helped to constitute the methodological and theoretical grounds that can help us to understand the intersection of the histories of archaeology and museums better. ${ }^{50}$

For instance, despite the strong connection of historical/archaeological museums to narratives of urban and national history - think only of the (pre-) history of the Egyptian Museum in Cairo or the National Museum of Iraq in Baghdad — scholarship has shown that 
municipalities and nation-states did not find it self-evident that they should institute or be connected to museums. ${ }^{51}$ In Britain, for example, the nineteenth-century archaeologist Charles Roach Smith criticized the Corporation of London for failing to implement a true archaeological museum of the city. ${ }^{52}$ How can we think through such controversies with reference to the wider museum literature? Meanwhile, practices in one sort of museum could help to shape and reshape practices in other sorts of museum whose identity might now seem far removed from such lineages. In France, Dominique Poulot has shown that the invention of city museums helped to reshape the local identity of national and provincial museums during the nineteenth century ${ }^{53}$ How, if at all, did this process of knowledge production intersect with the history of archaeology?

The answers to such questions align with the issues of visualisation and materiality noted earlier. Creating the various levels (municipal, university, national) of archaeological museum that now exist relied on the use of new techniques of display to build a narrative: models and dioramas were as essential to the stories museums attempted to tell as the objects they collected, the cases and cabinets that museums held those objects within and the way that curators displayed their collections. ${ }^{54}$ Also essential to these museum narratives was the material connection these institutions possessed with the field: sponsoring archaeological expeditions or acquiring objects from archaeological fieldwork conducted by others constituted a means of building a museum collection and claiming to hold authoritative, material knowledge about it. ${ }^{55}$ How did this relationship between museum and field play out, and who were the agents helping to construct it? Much of the knowledge-generating work done in museums has disappeared from view. To take just one example of many, as in the case of Shapin's invisible technicians (and as, also, in the case of the fossil preparators discussed elsewhere by Caitlin Wylie), the skilful yet undervalued museum assistants who did much of this work do not necessarily exist in institutional or disciplinary narratives. Additionally (and as ever), many of these 'lost' actors, like Petrie's protégé Margaret Murray, were women. ${ }^{56}$ Can we find them again? Skilful archival work may help but, as in the case of the discussion above, critical thinking about 'the archive' and its categories may also be necessary to achieve this goal.

Work in this special issue goes some way towards thinking through the archaeological museum archive and its possibilities. Melania Savino discusses the display of ancient artefacts in the Izmir Museum in what is now Turkey. Using the institution's archive, Savino illustrates how objects from local excavations were categorized and arranged in order to complement the founding of the new Turkish republic; after the end of the Ottoman Empire, 
Izmir was part of the land fought over by combatants in the (1919-1922) Graeco-Turkish War. Despite - or, more likely, because of - Greek interest in the ancient past of the nowTurkish Izmir region, the artefacts that had been recovered there were arranged in order to present the Turkish republic as the rightful inheritor and administrator of the various past identities that others claimed these objects to represent. In the case of Izmir, then, museum display took on a nationalist characteristic as a result of political expediency. Yet it is interesting to note that the Izmir Museum's curator, Aziz Ogan, enjoyed cordial relations with foreign archaeologists digging in the region whose interests in excavating there were connected far more with searching for the classical past. Savino's paper prompts further questions about what the relationship between nationalist museum display and archaeological excavation has been.

Meanwhile, Stéphane Van Damme details how the collection, display and interpretation of the so-called Pillar of the Boatmen (the Pilier des Nautes) illustrates how the biography of this particular thing can be used to demonstrate the salience of the notion of the 'boundary object' to the issues discussed above. ${ }^{57}$ The Pillar embodied the complex relationships between the national, Parisian and archaeological pasts as they emerged as objects of study in nineteenth-century France. As a result — and perhaps not so dissimilar from the case of the Izmir Museum discussed by Savino - the Pillar of the Boatmen acted as a boundary object: a thing upon which the diverse interests gathered around the French past could attach as they worked out that past's parameters. What other boundary objects exist that can help to illustrate the various ways in which the historical trajectories of collecting and the museum have developed? The articles in this special issue prompt further research directed towards answering this question.

\section{Object Conclusions: Ethics and 'the History of Archaeology'}

A final point. As this essay makes clear, archaeological objects and practices related to them raise a number of ethical questions, not least relating to the intersection of archaeology with the (multiple scales and forms of) imperialism. ${ }^{58}$ Archaeological objects are charged with a moral dimension. They represent something other than themselves, and are tied to issues of territoriality and loss, preservation and destruction, memory and mourning. Unsurprisingly, legal, ethical and emotional debates rage around how museums and governments should deal with collections of archaeological objects whose provenances are often, at best, opaque. ${ }^{59}$ Complicating this contention is the issue of the human remains also held by certain 
institutions, in addition to the past treatment of the human bodies used to dig these and other 'archaeological' objects up; treatment which intersects with issues of gender, race and class. ${ }^{60}$ As a result of these intersections and in the wake of the universalism of environmental history, archaeological objects have helped to create a civic community with an active interest in them, part of the "commons" that constitutes society. ${ }^{61}$ Where does the history of science stand in relation to this community? What can —or should-historians of science offer that might contribute to the contentious debates with which this community is engaged?

The answer to these questions lies in the discussions throughout this essay. The history of science can offer an oblique and novel perspective on the ways in which archaeological objects and the archaeological past have been formed. If we read 'against the grain' and between the lines of well-worn narratives relating to these objects, their archives and the forms of archaeological evidence that they have helped to create, we can write new and critical histories relating to the constitution of the archaeological domain and the communities that have gathered around it. These histories will allow us to interrogate the self-evident, unquestioned qualities of archaeological objects and the pasts and social forms that they have come to represent. And we can therefore productively highlight the ethical tensions that the making of the archaeological domain has generated.

In this special issue, for instance, Christina Riggs' article reads against the (archival) grain to highlight the tensions and power imbalances surrounding not only the excavation of the tomb of Tutankhamun, but also colonial archaeological practice more generally. Meanwhile, Melania Savino's paper highlights the imbalances surrounding the museum practice of the new Turkish republic, and William Carruthers' piece discusses the tensions and imbalances surrounding the constitution of archaeological evidence and EgyptianAmerican collaboration in the period of Egyptian decolonisation and the Cold War. Only with such tensions and imbalances revealed can we start to understand and grapple with the boundary objects which developed (as Carruthers' paper discusses) in an attempt to overcome them. This point relates not only to obviously geopolitical examples. As Stéphane Van Damme's paper highlights, such tensions are visible in other contexts, too. Making these tensions clear through an oblique but symmetrical reading, the history of science allows us the space to discuss the moral judgments and categories of evidence that have developed in relation to them. Who makes these judgments and constitutes these categories, why do they do so, and what have been the results?

Thinking through the history of archaeology with the history of science enables us to draw new conclusions. The dramatic extension of the archaeological domain no longer needs 
to be explained by discussing the epistemological boundaries of modern fields of philosophical knowledge. Indeed, we no longer need to — and perhaps even should not— think about 'the history of archaeology' as a category at all; to do so is to lend that domain more power and cohesion than it holds, as Boissinot's concept of archaeological emptiness emphasizes. Instead, the expansion of the archaeological domain is better explained due to the differentiation, partitioning and blurring of modern epistemological distinctions. Issues of disciplinarity, professionalization and scale are not unassailable objects, and neither are the institutions or archives that produce them. Indeed, the tensions that appear in connection to archaeology's blurring of modern epistemological distinctions and the boundary objects that developed in an attempt to overcome these concerns are as ripe for investigation as the articles we have compiled here illustrate. This special issue, in addition to the analytical themes that we have developed in relation to the articles within it, is an attempt to make that investigation happen.

\footnotetext{
${ }^{1}$ For discussion of this long history, see e.g. Margarita Díaz-Andreu, "Modèle naturaliste et modèle philologique dans l'archéologie européenne du XVIe au XIXe siècle”, in Javier Arce Martínez and Ricardo Olmos Romera (eds.), Historiografía de la arqueología y de la historia antigua en España (Madrid, 1991), 1924.

${ }^{2}$ Margarita Díaz-Andreu, A world history of nineteenth-century archaeology: Nationalism, colonialism, and the past (Oxford, 2007), 1.

${ }^{3}$ Díaz-Andreu, $A$ world history (ref. 2), 4. The best example of this phenomenon is probably Bruce Trigger, $A$ history of archaeological thought (New York, 2010; second, revised edition).

${ }^{4}$ Michel Foucault, Les mots et les choses, une archéologie des sciences humaines (Paris, 1966) and

L'archéologie du savoir (Paris, 1969); Judith Revel, Le vocabulaire de Foucault (Paris, 2002), 7.

${ }^{5}$ Gabriel Tarde, "L'archéologie et la statistique", Revue philosophique, xvi (1883), 363-84 and 492-511.

${ }^{6}$ By using such terminology, we refer to Bruno Latour, Reassembling the social: An introduction to actornetwork-theory (Oxford, 2005).

${ }^{7}$ Jacques-Antoine Dulaure, “Archaeographie des environs de la Houssaie et de Marle, département de Seine et Marne”, Mémoires de l'Académie celtique ou Recherches sur les antiquités celtiques, gauloises et françaises (Paris, 1810), 183.

${ }^{8}$ Alain Schnapp, The discovery of the past: the origins of archaeology (London, 1996); cf. Nathan Schlanger, The fabric of the past: Historical perspectives on the material culture of archaeology (Oxford, 2006).

${ }^{9}$ Schnapp, The discovery of the past (ref. 8), 238; cf. Alain Schnapp, "La méthode de Caylus", in Irène Aghion (ed.), Caylus, mécène du roi: Collectionner les antiquités au XVIII siècle (Paris, 2002), 53-63.

${ }^{10}$ For perspectives on this tension, see: Alison Wylie, Thinking from things: Essays in the philosophy of archaeology (Berkeley, CA, 2002); Alison Wylie, "The constitution of archaeological evidence: Gender politics and science", in Peter Galison and David J. Stump (eds.), The disunity of science: boundaries, contexts, and power (Stanford, 1996), 311-43; Alison Wylie, "Rethinking unity as a 'working hypothesis for philosophy': How archaeologists exploit the disunity of science", Perspectives on science, vii (1999), 293-317.

${ }^{11}$ R. E. Mortimer Wheeler, Archaeology from the earth (second, paperback edition; Harmondsworth, 1956 [1954]), 239-40.

${ }^{12}$ Jean-Paul Demoule and Bernard Stiegler (eds.), L'avenir du passé: Modernité de l'archéologie (Paris, 2008).

${ }^{13}$ On the social history of philology, see Paul Nelles "The library as an instrument of discovery: Gabriel Naudé and the uses of history", in Donald R. Kelley (ed.), History and the disciplines: The reclassification of knowledge in early modern Europe (Rochester, NY, 1997), 41-57. Cf.: Christopher Evans, "'Delineating objects': Nineteenth-century antiquarian culture and the project of archaeology", in Susan Pearce (ed.), Visions
} 
of antiquity: The Society of Antiquaries of London 1707-2007 (London, 2007), 266-305; Anthony Grafton, Forgers and critics: creativity and duplicity in Western scholarship (Princeton, 1990); Anthony Grafton, Worlds made by words: scholarship and community in the modern West (Cambridge, MA, 2009); Anthony Grafton and Ann Blair (eds.), The transmission of culture in early modern Europe (Philadelphia, 1990).

${ }^{14}$ See e.g. Annelise Riles, "Collateral expertise: legal knowledge in the global financial markets", Current anthropology, li (2010), 795-818, especially p. 797.

${ }^{15}$ For recent work on antiquarianism, see Alain Schnapp, "Towards a universal history of antiquarians", Complutum, xxiv (2013), 13-20; cf. Alain Schnapp, Lothar von Falkenhausen, Peter N. Miller and Tim Murray (eds.), World Antiquarianism: Comparative Perspectives (Los Angeles, 2014). For criticism of the Eurocentric nature of current antiquarian history, see Sudeshna Guha, Artefacts of history: Archaeology, historiography and Indian pasts (New Delhi, 2015), 43-46. For British examples of older work on antiquarianism, see Stuart Piggott, Ruins in a landscape: Essays in antiquarianism (Edinburgh, 1976) and Stuart Piggott, Ancient Britons and the antiquarian imagination: Ideas from the Renaissance to the Regency (London, 1989), 13-35.

${ }^{16}$ Henri Sauval, Histoire et recherches des antiquités de la ville de Paris (Geneva, 1973 [1724]), vol.2, 344.

${ }^{17}$ For relevant literature, see e.g.: Peter Burke, "Images as evidence in seventeenth-century Europe", Journal of the history of ideas, lxiv (2003), 273-96; Charlotte Guichard, Les amateurs d'art à Paris au XVIII siècle (Seyssel, 2008), 215; Michael Lynch, "The production of scientific images: Vision and re-vision in the history, philosophy, and sociology of science", in Luc Pauwels (ed.), Visual cultures of science: Rethinking representational practices in knowledge building and science communication (Hanover, 2006), 26-40; Samuel Smiles and Stephanie Moser (eds.), Envisioning the past: Archaeology and the image (Oxford, 2005).

${ }^{18}$ Philippe Boissinot, Qu'est-ce qu'un fait archéologique? (Paris, 2015).

${ }^{19}$ For the field and the history of science, see in particular Henrika Kuklick and Robert E. Kohler (eds.), Science in the field (Osiris, xi, 1996). For an example of effective field history dealing with a discipline closely related to archaeology, see Lyn Schumaker, Africanizing anthropology: Fieldwork, networks, and the making of cultural knowledge in Central Africa (Durham, NC, 2001). For the field and place-making, see e.g. Christopher Henke, "Making a place for science: The field trial", Social studies of science, xxx (2000), 483-511.

${ }^{20}$ Robert E. Kohler, Landscapes and lab-scapes: Exploring the lab-field border in biology (Chicago, 2002).

${ }^{21}$ See in particular Wendy Doyon, "On archaeological labor in modern Egypt", in William Carruthers (ed.), Histories of Egyptology: Interdisciplinary measures (New York, 2014), 141-56. For further perspectives, see: Stephen Quirke, Hidden hands: Egyptian workforces in Petrie excavation archives, 1880-1924 (London, 2010); Nathan Schlanger, "Manual and intellectual labour in archaeology: past and present in human resource management", in Stephanie Koerner and Ian Russell (eds.), Unquiet pasts: Risk society, lived cultural heritage, re-designing reflexivity (London, 2010), 161-71.

${ }^{22}$ Steven Shapin, "The invisible technician", American scientist, lxxvii (1989), 554-63.

${ }^{23}$ For Çatalhöyük and related field reflexivity in archaeology, see Ian Hodder, The archaeological process: an introduction (Oxford, 1999). For a recent example of such work related to the site, see Colleen Morgan and Daniel Eddisford, "Dig houses, dwelling, and knowledge production in archaeology", Journal of contemporary archaeology, ii (2015), 169-93.

${ }^{24}$ Elliott Colla, Conflicted antiquities: Egyptology, Egyptomania, Egyptian modernity (Durham, NC, 2007). For more on troublesome objects, see Mirjam Brusius, "Misfit objects: Layard's excavations in ancient

Mesopotamia and the biblical imagination in mid-nineteenth century Britain", Journal of literature and science, v (2012), 38-52.

${ }^{25}$ For France, see: Ruth Fiori, L'invention du vieux Paris: Naissance d'une conscience patrimoniale dans la capitale (Wavre, 2012); Christian Landes and Jean-Paul Demoule (eds.), La fabrique de l'archéologie en France (Paris, 2009). For heritage, Britain and Empire see e.g.: Paul Betts and Corey Ross, Heritage in the modern world: historical preservation in global perspective (Oxford, 2015; Past and present, supplement $\mathrm{x}$ ); Astrid Swenson and Peter Mandler (eds.), From plunder to preservation: Britain and the heritage of empire $c$. 1800-1940 (Oxford, 2013).

${ }^{26}$ See e.g.: Eve Gran-Aymerich, Naissance de l'archéologie moderne, 1798-1945 (Paris, 1998), 36-38; Alain Schnapp, "Archéologie et tradition académique en Europe aux XVIII et XIX ${ }^{\mathrm{e}}$ siècles", Annales: Économies, sociétés, civilisations, xxxvii (1982), 760-77. For a rather polemical account of the results of such boundary work, see Adam Stout, Creating prehistory: Druids, ley hunters and archaeologists in pre-war Britain (Oxford, 2008).

${ }^{27}$ For a critical and theoretically sophisticated history of the professional development of British archaeology, see Kitty Hauser, Shadow sites: Photography, archaeology, and the British landscape, 1927-1955 (Oxford, 2007).

${ }^{28}$ Roey Sweet, "The incorporated society and its public role", in Pearce (ed.), Visions of antiquity (ref. 13), 7597, especially p. 87.

${ }^{29}$ Sweet, "The incorporated society" (ref. 28), especially pp. 82-84. 
${ }^{30}$ Susan Pearce, "Antiquaries and the interpretation of ancient objects, 1770-1820", in Pearce (ed.), Visions of antiquity (ref. 13), 147-72, especially pp. 154-55.

${ }^{31}$ Philippa Levine, The amateur and the professional: Antiquarians, historians and archaeologists in Victorian England 1838-1886 (Cambridge, 1986), 50.

${ }^{32}$ On the archaeological anxieties of this period, see: Susanne Duesterberg, Popular receptions of archaeology: Fictional and factual texts in $19^{\text {th }}$ and early $20^{\text {th }}$ century Britain (New York, 2015); Stephanie Moser, Wondrous curiosities: Ancient Egypt at the British Museum (Chicago, 2006); Virginia Zimmerman, Excavating Victorians (Albany, NY, 2008).

${ }^{33}$ For the history of Egyptology and Egyptian archaeology in Britain during this period, see David Gange, Dialogues with the dead: Egyptology in British culture and religion, 1822-1922 (Oxford, 2013).

${ }^{34}$ Commission municipale du Vieux Paris, Année 1898-Procès-verbaux (Paris, 1899), 17.

${ }^{35}$ Joshua Arthurs, Excavating modernity: The Roman past in fascist Italy (Ithaca, NY, 2012).

${ }^{36}$ Fiona Rose-Greenland, "Looters, collectors and a passion for antiquities at the margins of Italian society", Journal of modern Italian studies, xix (2014), 570-82.

${ }^{37}$ For this history, see: Donald Malcolm Reid, Whose pharaohs? Archaeology, museums, and Egyptian national identity from Napoleon to World War I (Berkeley, CA, 2002); Donald Malcolm Reid, Contesting antiquity in Egypt: Archaeologies, museums, and the struggle for identities from World War I to Nasser (Cairo, 2015).

${ }^{38}$ With apologies to George W. Stocking, Jr. (ed.), Colonial situations: Essays on the contextualization of ethnographic knowledge (Madison, WI, 1991).

${ }^{39}$ Indra Sengupta, "Culture-keeping as state action: Bureaucrats, administrators, and monuments in colonial India", Past and present, supplement x (2015), 153-77.

${ }^{40}$ Bruce Trigger, “Alternative archaeologies: Nationalist, colonialist, imperialist”, Man, xix (1984), 355-70.

${ }^{41}$ Díaz-Andreu, A world history (ref. 2), part 2.

${ }^{42}$ For a significant recent work on the history of orientalism, see Suzanne L. Marchand, German orientalism in the age of empire: Religion, race, and scholarship (Cambridge, 2009).

${ }^{43}$ James A. Secord, "Knowledge in transit", Isis, xcv (2004), 654-72.

${ }^{44}$ Sujit Sivasundaram, "Sciences and the global: On methods, questions, and theory", Isis, ci (2010), 146-58.

${ }^{45}$ For more on this odd disentanglement, see Astrid Swenson, "The Heritage of Empire", in Swenson and Mandler (eds.), From plunder to preservation (ref. 25), 3-28.

${ }^{46}$ For the Petries, see e.g.: Margaret S. Drower, Flinders Petrie: A life in archaeology (London, 1985); Stephen Quirke, Hidden hands (ref. 21), which volume also constitutes an attempt to read the archaeological archive 'against the grain'.

${ }^{47}$ For recent work on UNESCO, see e.g.: Lynn Meskell, "UNESCO's World Heritage Convention at 40: Challenging the economic and political order of international heritage conservation", Current anthropology, liv (2013), 483-94; Tim Winter, "Heritage diplomacy", International journal of heritage studies, xxi (2015), 9971015. For relevant work on the archive, see e.g. the recent roundtable on "The archives of decolonization", American Historical Review, cxx (2015), 844-950.

${ }^{48}$ For scientific visualisation, see Lynch, "The production of scientific images" (ref. 17).

${ }^{49}$ See e.g. Brusius, "Misfit objects" (ref. 24); Soraya de Chadarevian and Nick Hopwood (eds.), Models: The third dimension of science (Stanford, CA, 2004).

${ }^{50}$ For critical work on the museum, see e.g.: Sam J. M. M. Alberti, Nature and Culture: Objects, Disciplines and the Manchester Museum (Manchester, 2012); Tony Bennett, Fiona Cameron, Nélia Dias, Ben Dibley, Rodney Harrison, Ira Jacknis, Conal McCarthy, Collecting, Ordering, Governing: Anthropology, Museums, and Liberal Government (Durham, NC, 2017); Robin Boast, "Neo-Colonial Collaboration: Museum as Contact Zone Revisited", Museum Anthropology 34 (1), 56-70; Frederick Bohrer, Orientalism and Visual Culture: Imagining Mesopotamia in Nineteenth-Century Europe (Cambridge, 2003); Sarah Byrne, Anne Clarke, Rodney Harrison and Robin Torrence (eds.), Unpacking the Collection: Networks of Material and Social Agency in the Museum (New York, 2011); Annie E. Coombes, Reinventing Africa: Museums, material culture and popular imagination in late Victorian and Edwardian England (New Haven, CT, 1994); Rodney Harrison, Sarah Byrne and Anne Clarke (eds.), Reassembling the Collection: Ethnographic Museums and Indigenous Agency (Santa Fe, NM, 2013); François Hartog and Jacques Revel (eds.), Les usages politiques du passé (Paris, 2001); Eilean Hooper-Greenhill, "The museum in the disciplinary society", in Susan M. Pearce (ed.), Museum studies in material culture (Leicester, 1989), 61-72; Moser, Wondrous Curiosities (ref. 32); Susan M. Pearce, "Objects as meaning; or narrating the past", in Susan M. Pearce (ed.), Objects of knowledge (new research in museum studies) (London, 1990), 125-40; Wendy M. K. Shaw, Possessors and Possessed: Museums, Archaeology, and the Visualization of History in the Late Ottoman Empire (Berkeley, CA, 2003); Carla Yanni, Nature's museums: Victorian science and the architecture of display (Baltimore, 1999). 
${ }^{51}$ For the Egyptian Museum see Reid, Whose pharaohs? (ref. 37). For the National Museum of Iraq see Magnus Thorkell Bernhardsson, Reclaiming a plundered past: Archaeology and nation building in modern Iraq (Austin, TX, 2005).

${ }^{52}$ Charles Roach Smith, Catalogue of the museum of London antiquities collected by, and the property of, Charles Roach Smith (London, 1854).

${ }^{53}$ Dominique Poulot, Surveiller et s'instruire: La Révolution française et l'intelligence de l'héritage historique (Oxford, 1996); Dominique Poulot, Une histoire des musées de France, XVIIIe-XXe siècle (Paris, 2005). Cf.: Daniel Fabre (ed.), Émotions patrimoniales (Paris, 2013); Nathalie Heinich, La fabrique du patrimoine: de la cathédrale à la petite cuillère (Paris, 2009).

${ }^{54}$ On models, for instance, see Christopher Evans, "Modelling Monuments and Excavations", in de Chadarevian and Hopwood, Models (ref. 49), 109-37.

${ }^{55}$ For such connections, see e.g. Bruce Kuklick, Puritans in Babylon: The ancient Near East and American intellectual life, 1880-1930 (Princeton, 1996).

${ }^{56}$ Kathleen L. Sheppard, The life of Margaret Alice Murray: A woman's work in archaeology (Lanham, MD, 2013); Caitlin Wylie, “'The artist's piece is already in the stone': Constructing creativity in paleontology laboratories", Social studies of science, xlv (2014), 31-55. William Carruthers would also like to thank Alice Stevenson for discussing such lost actors in relation to the Petrie Museum of Egyptian Archaeology at University College London.

${ }^{57}$ Susan Leigh Star and James R. Griesemer, “Institutional ecology, 'translations' and boundary objects: Amateurs and professionals in Berkeley's Museum of Vertebrate Zoology, 1907-39”, Social studies of science, xix, 387-420.

${ }^{58}$ For the ethics of archaeology, see Chris Scarre and Geoffrey Scarre (eds.), The ethics of archaeology: Philosophical perspectives on archaeological practice (Cambridge, 2006).

${ }^{59}$ The literature in this area is voluminous, not to mention contentious. For a volume collecting together various opinions, see Eleanor Robson, Luke Treadwell and Chris Gosden (eds.), Who owns objects? The ethics and politics of collecting cultural artefacts (Oxford, 2006). For a perspective on these issues in France and Germany, see Bénédicte Savoy, Patrimoine annexé: Les biens culturels saisis par la France en Allemagne autour de 1800 (Paris, 2003).

${ }^{60}$ For a recent, substantive reflection on these issues, see e.g. Christina Riggs, Unwrapping ancient Egypt (London, 2014).

${ }^{61}$ For examples of such communities, see Dominic Montserrat, Akhenaten: History, fantasy and ancient Egypt (London and New York, 2000). 